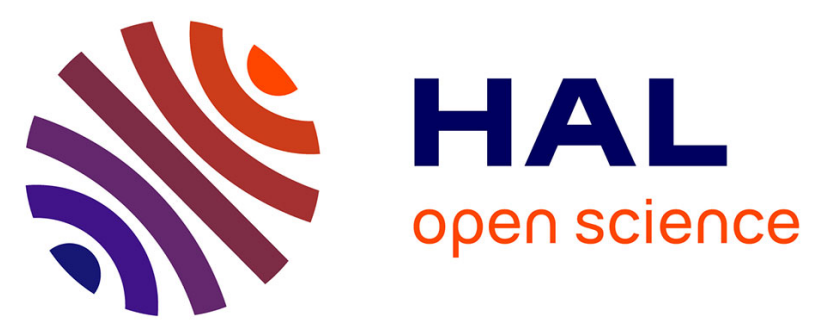

\title{
Measurement of affective state during chronic nicotine treatment and withdrawal by affective taste reactivity in mice: the role of endocannabinoids
}

Victoria C. Wing, Barbara Cagniard, Niall P. Murphy, Mohammed Shoaib

\section{- To cite this version:}

Victoria C. Wing, Barbara Cagniard, Niall P. Murphy, Mohammed Shoaib. Measurement of affective state during chronic nicotine treatment and withdrawal by affective taste reactivity in mice: the role of endocannabinoids. Biochemical Pharmacology, 2009, 78 (7), pp.825. 10.1016/j.bcp.2009.06.017 . hal-00509507

\section{HAL Id: hal-00509507 https://hal.science/hal-00509507}

Submitted on 13 Aug 2010

HAL is a multi-disciplinary open access archive for the deposit and dissemination of scientific research documents, whether they are published or not. The documents may come from teaching and research institutions in France or abroad, or from public or private research centers.
L'archive ouverte pluridisciplinaire HAL, est destinée au dépôt et à la diffusion de documents scientifiques de niveau recherche, publiés ou non, émanant des établissements d'enseignement et de recherche français ou étrangers, des laboratoires publics ou privés. 


\section{Accepted Manuscript}

Title: Measurement of affective state during chronic nicotine treatment and withdrawal by affective taste reactivity in mice: the role of endocannabinoids

Authors: Victoria C. Wing, Barbara Cagniard, Niall P. Murphy, Mohammed Shoaib

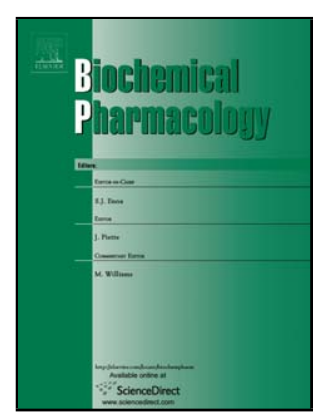

PII: S0006-2952(09)00486-9

DOI: doi:10.1016/j.bcp.2009.06.017

Reference: BCP 10226

To appear in: $\quad B C P$

Received date: $\quad$ 20-4-2009

Revised date: $\quad$ 5-6-2009

Accepted date: $\quad$ 12-6-2009

Please cite this article as: Wing VC, Cagniard B, Murphy NP, Shoaib M, Measurement of affective state during chronic nicotine treatment and withdrawal by affective taste reactivity in mice: the role of endocannabinoids, Biochemical Pharmacology (2008), doi:10.1016/j.bcp.2009.06.017

This is a PDF file of an unedited manuscript that has been accepted for publication. As a service to our customers we are providing this early version of the manuscript. The manuscript will undergo copyediting, typesetting, and review of the resulting proof before it is published in its final form. Please note that during the production process errors may be discovered which could affect the content, and all legal disclaimers that apply to the journal pertain. 
Measurement of affective state during chronic nicotine treatment and withdrawal by affective taste reactivity in mice: the role of endocannabinoids

Victoria C. Wing ${ }^{1}$, Barbara Cagniard ${ }^{2}$, Niall P. Murphy ${ }^{2}$ and Mohammed Shoaib ${ }^{1}$

1. Psychobiology Research Laboratories, Institute of Neuroscience, Newcastle University, Newcastle Upon Tyne, NE2 4HH, UK

2. Molecular Neuropathology Group, RIKEN Brain Science Institute, Wakoshi, Saitama, 3510198, Japan

Correspondence to:

Dr M Shoaib

Psychobiology Research Laboratories

Institute of Neuroscience

University of Newcastle

Newcastle Upon Tyne

NE2 4HH, UK

Tel: 00441912225529

Funding:

This work was funded by the RIKEN Brain Science Institute, and a BBSRC Japan Partnering Award. 


\begin{abstract}
Despite tobacco being highly addictive, it is unclear if nicotine has significant affective properties. To address this, we studied taste reactions to gustatory stimuli, palatable sucrose and unpalatable quinine, which are believed to reflect ongoing affective state. Taste reactivity was assessed during chronic nicotine administration and spontaneous withdrawal and the role of the endogenous cannabinoids was also investigated. C57BL6J mice were implanted with intra-oral fistula to allow passive administration of solutions. In the first study, taste reactivity was tracked throughout chronic vehicle or nicotine $(12 \mathrm{mg} / \mathrm{kg} / \mathrm{day})$ infusion via osmotic minipumps and spontaneous withdrawal following removal of minipumps. In the second study, the endocannabinoid CB1 receptor antagonist AM251 (1, 3 and $10 \mathrm{mg} / \mathrm{kg}$, intraperitoneal) or vehicle were acutely administered before taste reactivity measurement during chronic nicotine administration. Chronic nicotine treatment and spontaneous withdrawal did not influence taste reactions to sucrose or quinine. AM251 decreased positive reactions to sucrose and increased negative reactions to quinine. The effects of AM251 were respectively attenuated and enhanced in nicotine infused mice. These results suggest chronic nicotine exposure and withdrawal has no apparent affective sequelae, as probed by taste reactivity, and thus may not explain the difficulty tobacco-users have in achieving abstinence. In contrast, endocannabinoids elevates affective state in drug-naïve animals and changes in endogenous endocannabinoid tone may underlie compensations in affective state during chronic nicotine exposure.
\end{abstract}

Keywords: Nicotine, withdrawal, affective state, taste reactivity, endocannabinoids, mouse 


\section{Introduction}

Nicotine is considered the primary psychoactive agent responsible for tobacco addiction. The wide prevalence of tobacco addiction, and its resistance to treatment stands in patent contradiction to the observation that most individuals initially find nicotine exposure to be aversive, and even long-time nicotine addicts do not necessarily find nicotine exposure particularly rewarding [1]. Indeed, the subversiveness of nicotine addiction may be related to the paradoxical dissociation between the reinforcing properties of nicotine and any major rewarding effects.

Like many other pharmacological stimuli, the effects of nicotine becomes polarized when considered over a wide enough dose range, such that low doses of nicotine have rewarding (i.e. positively affective) effects, and high doses have aversive (i.e. negatively affective) effects. Preclinical studies show that the dose range over which these opposing effects occur is especially narrow for nicotine, and there is evidence that both effects can occur simultaneously [2]. In preclinical studies, the rewarding properties of stimuli are commonly assessed using intra-cranial self-stimulation (ICSS) or place conditioning paradigms [3]. Acute nicotine administration reduces ICSS reward thresholds [4] and induces a conditioned place preference [5], suggesting nicotine is capable of rewarding actions. However, nicotineinduced conditioned place preference is difficult to establish and occurs over an unusually narrow dose range [6-8]. Interestingly, studies suggest that the aversive effects of nicotine are more rapidly tolerated, thus unmasking a rewarding effect that may progressively contribute to establishing nicotine addiction $[9,10]$.

Smoking cessation results in an abstinence syndrome in heavy smokers that is generally believed to contribute to the high rate of relapse observed during the early stages of attempted smoking cessation $[11,12]$. However other studies have been unable to find a correlation between the severity of withdrawal and probability of relapse [13]. The affective 
symptoms, including depressed mood, anxiety and severe craving for nicotine [13, 14], are considered the more relevant to the continued use of nicotine $[15,16]$.

Recent evidence suggests that at least some actions of nicotine are mediated indirectly through the action of endocannabinoids [17]. For instance, endocannabinoid levels are increased in the limbic forebrain of rats chronically treated with nicotine [18]. CB1-receptor antagonism attenuates nicotine self-administration, reinstatement of nicotine-seeking behaviour [19-21] and nicotine-induced conditioned place preference [22]. Furthermore, the rewarding effects of nicotine measured using place preference conditioning are absent in CB1 knockout mice [23]. These studies have prompted the use of the CB1 receptor antagonist rimonabant as a smoking cessation aid in humans, which has met with some success [24]. Recent studies have also identified a role for endocannabinoids in mood and anxiety states, both of which are important aspects of nicotine withdrawal, although both anxiolytic and anxiogenic effects of CB1 receptor blockade have been reported [25], thus further clarification of these processes is needed.

The current study had two aims. The first was to seek support for the notion that nicotine induces a positive affective state, whereas withdrawal from chronic nicotine administration is an aversive experience. To address this, we applied the measurement of taste reactivity as a probe of affective state, as previous studies suggest that taste reactivity patterns to palatable and unpalatable tastants reflect basal and ongoing "core" affective states [26]. For example, morphine and amphetamine, increase sucrose palatability $[27,28]$ and suppress aversive taste reactions to the bitter tastant quinine [29-31], suggesting these drugs raise affective state in a manner akin to "reward". We analysed taste reactivity patterns to sucrose and quinine during continuous nicotine infusion and spontaneous withdrawal. We predicted that acute nicotine exposure would induce a shift towards more negative reactions, followed by a progressive shift towards more positive reactions. Following spontaneous nicotine withdrawal, we expected a second shift towards more negative reactions, such a response 
might support negative reinforcement views of withdrawal in the maintenance of nicotine addiction [32].

The second aim was to seek evidence for an involvement of endocannabinoid activity in mediating any affective properties of long-term nicotine administration. To this end, we analysed taste reactivity patterns after blockade of endogenous cannabinoid tone, using the CB1-receptor antagonist AM251 [33, 34] during continuous nicotine infusion. We predicted that blocking endogenous cannabinoid tone would shift taste reactions towards more negative responses, and this effect would be stronger in mice undergoing chronic nicotine administration. This was based on the hypothesis that endogenous cannabinoids progressively acquire mediatory roles in the affective properties of nicotine.

\section{Methods}

\subsection{Subjects}

Subjects were male C57BL/6J mice (Nihon Clea, Tokyo, Japan) aged 8 weeks on arrival. Animals were individually housed with food and water provided ad libitum in a temperature controlled colony room. All measurements of taste reactivity were carried out during the light period (07:00 - 19:00). Experimental protocols were approved by the RIKEN Brain Science Institute review committee and were in accord with the National Research Council Guide for the Care and Use of Laboratory Animals. All efforts were made to minimize the number of animals used and their suffering.

\subsection{Drugs}

Osmotic pumps (Alzet, Durect Coporation, Cupertino, CA) were used to continuously infuse $0.9 \% \mathrm{NaCl}$ vehicle or nicotine (Sigma-Aldrich, Tokyo, Japan) at a dose of $12 \mathrm{mg} / \mathrm{kg} / \mathrm{day}$ of free base (32.4 mg/kg/day nicotine salt, pH corrected to $7.2 \pm 0.2$ using $1 \mathrm{M} \mathrm{NaOH})[35,36]$. Depending on the duration of nicotine exposure required, model 1002 (maximum 14 day 
infusion and mean flow rate of $0.25 \mu \mathrm{l} /$ hour) or model 1004 (maximum 28 days infusion and mean flow rate of $0.11 \mu \mathrm{l} / \mathrm{hour}$ ) pumps were used. The concentration of nicotine solution used to fill the pumps was adjusted according to the flow rate of the pump model to provide the desired dose of nicotine infusion. The CB1 antagonist AM251 (Tocris, Ellisville, MO, USA) was suspended in a vehicle of $0.1 \%$ methylcellulose (Sigma-Aldrich, Tokyo, Japan) and $10 \%$ Tween-80 (Sigma-Aldrich, Tokyo, Japan) by sonication at $30^{\circ} \mathrm{C}$ for 30 minutes. The drug was administered intraperitoneally (i.p., in $10 \mathrm{ml} / \mathrm{kg}$ ) at doses of 1,3 and $10 \mathrm{mg} / \mathrm{kg}$ $[37,38]$.

\subsection{Surgery}

Mice were anaesthetised by i.p. injection of ketamine (100 mg/kg, Wako, Osaka, Japan) and xylazine (10 mg/kg, Sigma). Penicillin (0.1 ml; Benzylpenicillin potassium 200,000 Units, Meiji Seika Kaisha, LTD. Tokyo, Japan) was administered post-operatively. Mice were implanted with chronic bilateral oral cannula (polyethylene PE-50 tubing, Intramedic, Balsta, Sweden) as described by Cagniard and Murphy (2009). The intraoral end of the cannula was heat-flared to an approximate diameter of $3 \mathrm{~mm}$. The cannulae were inserted lateral to the first molar, and routed subcutaneously posterior to the eye, to exit the top of the head where they were fixed to a screw anchored to the skull using dental cement (Yamahachi Dental, Gamagoorishi, Aichi, Japan). To avoid obstruction of the cannulae during the recovery period, a silk thread was inserted and the loose end of the cannula was heat-sealed until the start of infusions. Animals were left to recover for at least a week before any further experimental procedures and body weight was monitored throughout the studies. Osmotic minipumps were subcutaneously implanted between the shoulder blades, to avoid impeding the animals' movement, under ketamine/xylazine anaesthesia (see above) and the incision closed with surgical clips.

\subsection{Locomotor activity and temperature measurement}


Horizontal locomotor activity was measured for 40 minutes in a grey $25 \times 25 \times 40 \mathrm{~cm}$ enclosed arena using automated locomotor monitors (Truscan, Coulbourn Instruments, Allentown, PA, USA). A microprobe digital thermometer (Physitemp, Clifton, NJ, USA) was used for measuring rectal temperature.

\subsection{Taste reactivity testing}

The taste reactivity measurement chamber consisted of a raised Plexiglas cylinder $(30 \mathrm{~cm}$ high $\times 13 \mathrm{~cm}$ diameter) placed on a transparent Plexiglas floor over an angled mirror reflecting a ventral view of the mouse that allowed videotaping of the mouth of the animal using a digital video camera (DCR PC101, Sony Corporation, Japan) directed at the mirror. Taste reactivity was conducted at a specified time of day throughout the studies. Mice were habituated to the testing chamber on three consecutive days prior to minipump implantation and taste reactivity testing. Each habituation session lasted $10 \mathrm{~min}$. On the last day of habituation, mice were habituated to the taste reactivity procedure with a single oral infusion of drinking water (0.1 ml volume, 1 minute duration).

For taste reactivity testing, a delivery line constructed of PE-50 polyethylene tubing was connected to one of the oral cannulae by a polyethylene PE-100 nozzle and connected to a $1 \mathrm{ml}$ syringe mounted on an automated syringe pump (Harvard Apparatus, Holliston, MA, USA). The entire length of tubing was filled with the appropriate solution and a small amount of solution was infused into the mouth of the animal to verify the patency of the cannula. Mice were adapted to the testing chamber for $9 \mathrm{~min}$. They then received an infusion of $0.3 \mathrm{M}$ sucrose solution followed 9 min later by an infusion of $0.0005 \mathrm{M}$ quinine. The concentrations of sucrose and quinine were chosen based on data from our laboratory [39] and other previous taste reactivity studies using mice [40], as to elicit an intermediate level of positive and negative reactions respectively, thus allowing the possibility of changes in either direction. Sucrose was always infused first as the positive hedonic reactions are more vulnerable to disruption than negative reactions $[41,42]$. Each infusion was $0.1 \mathrm{ml}$ in volume 
and lasted 1 min, during which time mice were videotaped. The cannula was flushed with 1 $\mathrm{ml}$ of drinking water at the end of each infusion.

\subsection{Analysis of taste reactions}

Videotaped trials were analyzed frame-by-frame (30 frames per sec) by an observer blind to treatment (tastant or drugs) using video editing software (Final Cut Pro, Apple Inc, Cupertino, CA). Scoring was performed manually and recorded using software for scoring observational data (ODlog, Macropod Software, http://www.macropodsoftware.com/). Behavioral reactions were classified as positive, aversive and neutral according to previous studies in mice $[39,43]$. Positive hedonic reactions included rhythmic tongue protrusions, single tongue protrusions, and paw licking. Aversive reaction patterns included gapes, chin rubbing, head shaking, forepaw flailing, and face washing. Neutral reactions were those less strongly linked with positive or aversive evaluations, such as mouth movements, passive drip of the solution, and grooming. Reactions that occur in bouts of moderate duration (rhythmic tongue protrusions, chin rubbing, and paw pushing) were scored in bins of 2 seconds. Reactions that have longer bout durations (paw licking, face washing, rhythmic mouth movements, passive drips and grooming) were scored in 5 second bins and those which occur as single behaviors were scored separately. These time bins allow the contribution of taste reactivity components with different relative frequencies to be comparable in their contribution to the final positive or aversive score [26]. The general behavioral activity measures scored were horizontal activity (scored as movement of all four paws) and rearing (rising on the hind feet).

\subsection{Experiment 1: Measurement of taste reactions during chronic nicotine infusion and} withdrawal

Assessment of taste reactivity patterns to sucrose and quinine tastants was used as a measure of ongoing affective state of mice during chronic nicotine exposure and spontaneous withdrawal (refer to Figure 1.f). Following surgical implantation of the oral 
cannulae, recovery, and habituation to the taste reactivity procedure, mice were implanted with 14 day osmotic minipumps containing vehicle $(n=8)$ or nicotine $(n=7)$. Mice underwent taste reactivity testing the following day and on day 11 of chronic nicotine exposure. On the 12th day, pumps were rapidly removed under brief ketamine/xylazine anaesthesia and taste reactivity assessed $15 \mathrm{hrs}$ and 7 days later. Previous studies show that acute nicotine administration produces changes in locomotor activity (depression followed by tolerance/sensitization) and hypothermia in mice [44-47]. However the effect of continuous infusion on these measures is less well established. Rectal temperature measurement was followed by locomotor activity assessment on days 2, 6 and 10 of nicotine treatment and on day 2 and 6 of nicotine withdrawal. These days were selected as not to interfere with evaluation of the primary measure taste reactivity but allow assessment across the nicotine exposure and withdrawal periods. Measurements were conducted at the same time of day as taste reactivity testing.

\subsection{Experiment 2: Effect of cannabinoid antagonism on taste reactions during chronic nicotine infusion}

The role of the endogenous cannabinoid tone in mediating affective reactions to nicotine was examined by studying taste reactivity patterns in drug-naïve and chronically nicotine treated mice following acute pre-treatment with the CB1-receptor antagonist AM251 (refer to Figure 3.f). Thus, following surgical implantation of the oral cannulae, recovery, and habituation to the taste reactivity procedure, mice were implanted with osmotic minipumps prepared to infuse either vehicle $(n=6)$ or nicotine $(n=6)$ for 28 days. Assessment of taste reactivity was conducted during the later period of chronic nicotine exposure (days 15 to 21). Vehicle or AM251 were administered 21 minutes before placement of mice into the testing chamber, i.e. $30 \mathrm{~min}$ before sucrose infusion and $40 \mathrm{~min}$ before quinine infusion. Mice were injected with vehicle on day 15 to measure baseline taste reactions, and control for the acute injection procedure, in both vehicle- and nicotine-treated subjects. Ascending doses of AM251 (1, 3 and $10 \mathrm{mg} / \mathrm{kg}$ ) were then examined in both groups; tests were carried out on 
alternate days (i.e. days 17,19 and 21 ) to prevent possible progressive accumulation of the drug due to its relatively long half-life (22hr; [48]. The ascending dosing regimen was employed to minimise the impact of any variation in taste reactivity responses which may occur as the result of repeated exposure to the flavoured solutions. It also limited the study to a feasible size and reduced the number of animals required in accordance with the Animals Scientific Procedures Act, UK (1986).

\subsection{Statistical analyses}

Statistical analyses were conducted using SPSS statistics software version 15.0 (Chicago, Illinois, USA) with significance level set at $p<0.05$. Data were analyzed by a two-factor repeated measure analysis of variance (ANOVA) with taste reactivity test (in experiment 1 : day 1 and 11 of chronic treatment and day 1 and 7 after minipump removal; in experiment 2: 0, 1, 3 or $10 \mathrm{mg} / \mathrm{kg}$ AM251 pre-treatment) as the repeated within-subject factor and treatment (vehicle or nicotine exposure) as the between subject factor. Effects of taste reactivity test within the vehicle or nicotine treated groups were revealed by separate one factor repeated ANOVA followed by post-hoc Bonferroni pairwise comparisons when appropriate. Independent t-tests were used to establish differences between the vehicle and nicotine groups for each taste reactivity test. Data are expressed as group mean \pm standard error.

\section{Results}

Mice returned to post-operative weight following implantation of the intra-oral cannulae and their weight remained constant throughout the study indicating the surgery did not affect feeding (data not shown). The scores for all taste reactions observed during these studies are shown in Tables 1 and 2; reactions such as chin rubbing, gapes, face washing, and 
passive drip of the solution were not observed throughout any of the studies. Results for selected measures are shown in the figures.

\subsection{Experiment 1: Measurement of taste reactions during chronic nicotine infusion and} withdrawal

The results of this study are shown in table 1. As previously reported, mice showed strong positive taste reactions to intraoral infusion of sucrose (Figure 1) and extensive negative taste reactions to quinine (Figure 2) $[39,43]$. There were no significant interactions between testing session and treatment group or differences between vehicle and nicotine treated subjects in any taste reactions throughout chronic nicotine treatment and spontaneous withdrawal.

Statistical analysis showed significant changes in taste reactivity measures over the course of the chronic infusion period in both vehicle and nicotine treated groups. That is, in both groups there was a decrease in the neutral reaction of mouth movements in response to sucrose infusion (Fig 1e; $f(3,39)=2.88, p=0.048)$ during repeated testing of taste reactivity, possibly due to habituation or desensitization in the response. In contrast, there was a trend towards increasing aversive reactions to quinine across sessions (Fig $2 b ; f(3,39)=2.390$, $\mathrm{p}=0.083$ ). No differences were observed in locomotor activity and rectal temperature measurements (taken on days intervening taste reactivity measures) between vehicle and nicotine treated animals (data not shown).

The similarity in taste reactivity patterns during vehicle and nicotine infusion, and spontaneous withdrawal indicates that by this measure, chronic nicotine exposure and abrupt withdrawal has no observable effect on affective state.

\subsection{Experiment 2: Effect of cannabinoid antagonism on taste reactions during chronic} nicotine infusion 
The results of this study are shown in table 2 and figures 3 and 4. As AM251 was administered repeatedly to mice at increasing doses, our analysis focused to identifying differences between chronically vehicle or nicotine infused mice that were not simply a product of repeated testing, but due specifically to AM251 administration. Thus we sought evidence of main effects of AM251 administration, interactions between AM251 administration and chronic nicotine infusion, or evidence of differences in the response to AM251 treatment between chronically vehicle and nicotine infused animals.

Two-way ANOVAs determining main effects of increasing AM251 dose demonstrated a trend towards decreased overall positive reactions to sucrose $($ Fig $3 a ; f(3,30)=2.707$, $p=0.063)$, a significant decrease in the positive reaction paw licking during sucrose infusion (Fig $3 e ; f(3,30)=4.286, p=0.012)$. There was also a significant decrease in positive reactions to quinine (Fig 4a; $f(3,30)=3.209, p=0.037)$. In contrast, AM251 increased overall negative reactions to quinine $(\mathrm{Fig} 4 \mathrm{~b} ; \mathrm{f}(3,30)=10.434, \mathrm{p}<0.001)$ and individual negative reactions during quinine infusion including flails (Fig $4 \mathrm{e} ; \mathrm{f}(3,30)=8.008, \mathrm{p}<0.001)$ and head shakes (Fig $4 f ; f(3,30)=7.982, p<0.001)$.

There interaction between AM251 dose and nicotine infusion did not reach statistical significance. However, within group one-way ANOVAs were able to demonstrate the effect of AM251 on sucrose and quinine palatability was respectively attenuated and enhanced in animals chronically treated with nicotine. Indeed, only chronically vehicle infused mice showed a statistically significant, and dose-orderly, decrease in paw licking with increasing AM251 dose during sucrose infusion (Fig $3 e ; f(3,15)=5.04, p=0.013$, one-way ANOVA) with a significant reduction compared to vehicle at $3 \mathrm{mg} / \mathrm{kg}(\mathrm{p}=0.049)$. The effect of AM251 on overall positive reactions in response to sucrose did not reach significance (Fig 3a; $f(3,15)=1.807, p=0.189$, one-way ANOVA), In contrast, AM251 caused a dose-orderly increase in overall negative reactions to quinine in both vehicle (Fig 4b; $f(3,15)=3.604$, $p=0.039)$ and nicotine (Fig 4b; $f(3,15)=7.927, p=0.002$, one-way ANOVA). However, the 
effects of AM251 were more robust in nicotine treated animals compared to controls with post-hoc tests revealing significant increases compared to the vehicle at $3(p=0.044)$ and 10 $\mathrm{mg} / \mathrm{kg}(\mathrm{p}=0.016)$ in nicotine but not vehicle treated animals. AM251 only increased flails produced during quinine infusion in the nicotine treated group (Fig $4 \mathrm{e} ; \mathrm{f}(3,15)=7.077$, $\mathrm{p}=0.003$, one-way ANOVA) and $10 \mathrm{mg} / \mathrm{kg}$ produced significantly higher scores than vehicle $(p=0.02)$ and $1 \mathrm{mg} / \mathrm{kg}(\mathrm{p}=0.036)$. Head shakes produced by quinine infusion were also significantly increased by AM251 in both vehicle (Fig 4f; $f(3,15)=4.745, p=0.016$, one-way ANOVA) and nicotine treated groups (Fig 4f; $f(3,15)=4.937, p=0.014$, one-way ANOVA), which compared to vehicle was significantly increased at $10 \mathrm{mg} / \mathrm{kg}(p=0.034$ and $p=0.026$ respectively). However, in nicotine treated animals, head shakes were also enhanced at lower doses of AM251, $1(p=0.003)$ and $3 \mathrm{mg} / \mathrm{kg}(\mathrm{p}=0.027)$, and there was a significant difference between vehicle and nicotine treated groups at the $1 \mathrm{mg} / \mathrm{kg}$ dose and near significance at $3 \mathrm{mg} / \mathrm{kg}$ ( $p=0.04$ and $p=0.06$ respectively, independent $\mathrm{t}$-tests).

There were also differences in the general behavioural activity responses to AM251 in the vehicle and nicotine treated groups. There was a significant effect of AM251 on overall behavioural activity during sucrose infusion (Fig $3 d ; f(3,30)=3.395, p=0.03$ ), which interacted with chronic treatment $(f(3,30)=3.357, p=0.032)$. However there was only a significant effect of AM251 in the nicotine group $(f(3,15)=8.145, p=0.002$, one-way ANOVA) with a dosedependent decrease in behavioural activity and a significant difference compared to vehicle after pre-treatment with $1(p=0.026), 3(p=0.015)$ and $10 \mathrm{mg} / \mathrm{kg}(p=0.006)$. This was due to the significant effect on horizontal activity $(f(3,30)=4.045, p=0.016$, two-way ANOVA) in the nicotine group $(f(3,15)=3.603, p=0.039$, one-way ANOVA $)$.

In summary, taste reactivity measures switched to a more aversive pattern following blockade of the endogenous cannabinoid tone indicating this system acts to raise basal affective state under normal conditions. CB1-receptor antagonism also exposed a 
compensation in affective state that takes place in response to chronic nicotine treatment; an effect which is at least in part mediated by the endocannabinoid system.

\section{Discussion}

This study used observable shifts in taste reactions to palatable and unplatable tastants as an index of affective state. Chronic nicotine exposure and spontaneous withdrawal had no detectable effects on taste reactivity, suggesting no major changes in affective state. However, evidence was found for changes in endogenous endocannabinoid tone which might underlie compensations in affective state occurring during chronic nicotine exposure.

\subsection{Effects of nicotine exposure}

A previous study in rats by Parker and Doucet (1995) examined the ability of nicotine to modify the palatability of tastants. Acute challenge with low doses of nicotine $(0.4 \mathrm{mg} / \mathrm{kg}, \mathrm{s.c})$ suppressed aversive reactions to quinine and enhanced positive reactions to sucrose, suggesting that in common with other abused drugs, nicotine enhances the affective evaluation of solutions [27-31]. In the same study, three weeks of repeated nicotine administration (twice daily injections progressively increased from 0.4-0.8 mg/kg, s.c) eliminated the ability of nicotine to modulate palatability, indicating tolerance to the effects of nicotine. Termination of daily nicotine administration, which assumedly creates a withdrawal state, was accompanied, paradoxically, by an increase in the positive evaluation of sucrose [49]. These findings stand in contrast to those of the current study but clearly the protocols employed differ in a number of key aspects including the species of rodent and crucially the mode of nicotine administration. Nicotine delivery by continuous subcutaneous infusion was intended to produce a steady state nicotine administration, rather than repeated bolus exposures, which may be unable to modulate palatability. This may also explain the absence of nicotine-induced hypothermia $[50,51]$ and locomotor depression [52] observed in the 
current study as these effects of nicotine undergo rapid tolerance upon chronic exposure [53]. Notably, the absence of any changes in taste reactions in the current study, particularly as they pertain to affective state, is in accord with previous studies showing that continuous nicotine infusion does not modulate "reward thresholds" in ICSS paradigms [54].

\subsection{Effect of nicotine withdrawal}

Previous theoretical constructs designed to explain the nature of nicotine addiction have emphasized the negatively reinforcing effects of pharmacological withdrawal from nicotine [59]. Behavioural correlates of nicotine withdrawal, both spontaneous and precipitated, have been evaluated using various paradigms [54,60,61]. Place conditioning studies suggest that nicotine withdrawal is aversive as reflected in mild avoidance of environments paired with antagonist-induced nicotine withdrawal [62]. Other models such as the black and white test boxes and changes in auditory startle that suggest environments paired with nicotine withdrawal are anxiogenic $[63,64]$. In the forced swim test animals, nicotine-withdrawn animals exhibit a depression-like behaviour [65] and nicotine withdrawal is associated with higher thresholds in ICSS studies thought to model the anhedonia (inability to experience pleasure) observed in humans $[54,66]$. These studies provide compelling evidence that simple pharmacological withdrawal from nicotine produces both an axiogenic and anhedonic state. Nonetheless, the current study yielded no evidence to support the tenet that spontaneous withdrawal from the pharmacological effects of nicotine induced any change in affective state, at least as it is reflected in taste reactivity, which may be due to several reasons.

An intermediate nicotine dose (12 $\mathrm{mg} / \mathrm{kg} /$ day) was employed based on previous studies in which termination of $6.3-24 \mathrm{mg} / \mathrm{kg} /$ day nicotine produced an abstinence syndrome in terms of physical withdrawal, contextual fear responses and anxiety-like behaviors [35, 36, 67 , 68].Thus, taste reactivity may simply be unable to, or be insufficient to detect an affective 
changes associated with nicotine withdrawal. A recent ICSS study in mice detected a decrease in reward function during spontaneous withdrawal from 14 days exposure to 24 $\mathrm{mg} / \mathrm{kg} /$ day of nicotine [69], however, another study reported a dose of $40 \mathrm{mg} / \mathrm{kg}$ over 28 days was needed to produce changes in ICSS thresholds [70]. Furthermore, motivational impairment as measured by ICSS is precipitated at lower doses of a nicotinic antagonist than somatic signs of withdrawal $[54,70]$. Therefore, compared to taste reactivity, ICSS may be a particularly sensitive indicator of relatively subtle affective properties of nicotine withdrawal. In addition, although the two paradigms are both considered to represent affective measures, they may in fact be probing different aspects of affective state which may be altered differently during nicotine withdrawal. That is, ICSS thresholds reflect the motivation to obtain rewarding stimuli whereas taste reactivity provides a non-operant assessment of 'core affective processes'. Either way, when one considers that a dose of 12 $\mathrm{mg} / \mathrm{kg} /$ day is equivalent to approximately 30 administrations of the dose of nicotine commonly used to induce conditioned place preferences in mice [71-73], the lack of effects with this substantial amount of nicotine are quite striking.

The high doses and prolonged exposure to nicotine needed to produce changes in ICSS thresholds [70] and lack of effects observed in the current study suggest, given that taste reactivity reliably indexes changes in affective state [26], nicotine withdrawal is not a robust and generalised affective event. Our results suggest changes in affective state that simply depend on direct pharmacological actions of nicotine administration, or withdrawal from chronic nicotine exposure may not be the main drivers of nicotine addiction. If so, additional or alternative factors must underlie the great difficulty smokers have in achieving abstinence. Animal and human research has highlighted the involvement of non-pharmacological stimuli in nicotine addiction [74], showing important roles for conditioned environmental stimuli paired with nicotine delivery [75] and the environment in which drug administration takes place $[76,77]$ in smoking behaviour and relapse. And more recently, it has been proposed that nicotine also maintains self-administration via a secondary 'reinforcement-enhancing' 
mechanism characterised by enhancement of the motivational value of alternative reinforcers [78]

\subsection{Endogenous cannabinoids and nicotine tolerance/dependence}

The second study reported here suggests that endogenous cannabinoid tone buoys up basal affective state as CB1-receptor blockade produced changes in taste reactivity indicative of a general decrease in affective state. That is, a reduction of positive reactions to sucrose and an increase in negative reactions to quinine, as observed in the vehicle control group. A similar reduction in the palatability of sucrose and quinine by the CB-1 receptor antagonist AM251 has been reported in previous taste reactivity studies $[79,80]$. Furthermore, the endocannabinoid agonist delta-9-tetrahydrocannabinol enhanced sucrose [80] and quinine [79] palatability. Studies show that cannabinoid administration directly into the nucleus accumbens amplifies the positive affective impact of sucrose, without altering negative reactions to bitter quinine [42]. Interestingly, the present data indicate that endogenous cannabinoid tone underlies both positive and negative reactions to gustatory stimuli. The differences in findings between this and previous studies may be due to the route of administration (i.e. intra-accumbens versus systemic) or the concentration of quinine used, as a previous study found modification of quinine aversion is only possible at lower concentrations [79].

Increasing evidence points to an involvement of endogenous cannabinoids in the reinforcing effects of drugs of abuse, including nicotine [19-22, 81], though endocannabinoids may have lesser roles in mediating the subjective effects [21] and physical dependence [23] produced by nicotine. In the current study, blockade of endogenous endocannabinoid signalling during chronic nicotine infusion modified taste reactivity patterns in a manner that differed between chronic nicotine- and vehicle-exposed mice. This result suggests that enhanced endogenous endocannabinoid signalling maintains affective state at a pre-defined "set-point" during chronic nicotine exposure. Further conclusions can be drawn by examining the nature of the 
taste reactivity. That is, endocannabinoid blockade produced more robust negative taste reactions to quinine in nicotine-treated animals than in vehicle controls, indicating endocannabinoids underlie a compensatory increase in affective state, in turn suggesting that chronic nicotine exposure would otherwise depress affective state. Conversely, chronic nicotine exposure appeared to attenuate other aspects of the negative affective state produced by AM251, such as the reduced positive reactions to sucrose, emphasising the diverse stimulus properties of nicotine. The opposing effects of CB1-receptor antagonism on positive and negative reactions to the gustatory stimuli support the hypothesis for independent control processes for positive and aversive aspects of palatability [82] and that overall affective state is the sum of the contribution of individual sub-components that can act in opposing directions. Furthermore, the de-sensitization of positive reactions and sensitization of negative reactions suggests chronic nicotine exposure results in the brain becoming more 'aversion-controlled' than 'pleasure-controlled'.

In summary, the data presented suggest nicotine has minimal affective properties as chronic nicotine exposure and spontaneous withdrawal did not alter affective state as probed by taste reactivity. Thus, the subjective pleasurable effects of nicotine and aversive nature of nicotine withdrawal as measured using the taste reactivity procedure do not translate to human nicotine addiction, since these motivational effects of nicotine are considered to be paramount in driving tobacco dependence. The role of the endogenous cannabinoid system in affective state changes was established: under drug-free conditions endocannabinoids act to elevate affective state and furthermore underlie the compensation in affective state produced in response to chronic nicotine exposure.

\section{Acknowledgements}


We thank the RIKEN Brain Science Institute and the Institute of Neuroscience, University of Newcastle for supporting this research. This collaboration was supported by a BBSRC Japan Partnering Award. 


\section{References}

[1] Perkins KA, Grobe JE, Fonte C, Goettler J, Caggiula AR, Reynolds WA, et al. Chronic and acute tolerance to subjective, behavioral and cardiovascular effects of nicotine in humans. Journal of Pharmacology \& Experimental Therapeutics 1994;270:628-38.

[2] Gommans J, Stolerman IP, Shoaib M. Antagonism of the discriminative and aversive stimulus properties of nicotine in C57BL/6J mice. Neuropharmacology 2000;39:2840-7.

[3] Sanchis-Segura C, Spanagel R. Behavioural assessment of drug reinforcement and addictive features in rodents: an overview. Addiction Biology 2006;11:2-38.

[4] Huston-Lyons D, Kornetsky C. Effects of nicotine on the threshold for rewarding brain stimulation in rats. Pharmacology, Biochemistry \& Behavior 1992;41:755-9.

[5] Fudala PJ, Teoh KW, Iwamoto ET. Pharmacologic characterization of nicotineinduced conditioned place preference. Pharmacology, Biochemistry \& Behavior 1985;22:237-41.

[6] Fudala PJ, Iwamoto ET. Further studies on nicotine-induced conditioned place preference in the rat. Pharmacology, Biochemistry \& Behavior 1986;25:1041-9.

[7] Clarke PB, Fibiger HC. Apparent absence of nicotine-induced conditioned place preference in rats. Psychopharmacology 1987;92:84-8.

[8] Le Foll B, Goldberg SR. Nicotine induces conditioned place preferences over a large range of doses in rats. Psychopharmacology 2005;178:481-92.

[9] Iwamoto ET, Williamson EC. Nicotine-induced taste aversion: characterization and preexposure effects in rats. Pharmacology, Biochemistry \& Behavior 1984;21:527-32.

[10] Shoaib M, Stolerman IP. The NMDA antagonist dizocilpine (MK801) attenuates tolerance to nicotine in rats. Journal of Psychopharmacology 1996;10:214-8.

[11] Hughes JR, Gulliver SB, Fenwick JW, Valliere WA, Cruser K, Pepper S, et al. Smoking cessation among self-quitters. Health Psychology 1992;11:331-4.

[12] Shiffman SM, Jarvik ME. Smoking withdrawal symptoms in two weeks of abstinence. Psychopharmacology 1976;50:35-9.

[13] Hughes JR, Gust SW, Skoog K, Keenan RM, Fenwick JW. Symptoms of tobacco withdrawal. A replication and extension. Archives of General Psychiatry 1991;48:529.

[14] Hughes JR, Hatsukami D. Signs and symptoms of tobacco withdrawal. Archives of General Psychiatry 1986;43:289-94.

[15] Markou A, Kosten TR, Koob GF. Neurobiological similarities in depression and drug dependence: a self-medication hypothesis. Neuropsychopharmacology 1998;18:13574.

[16] Koob GF, Caine SB, Parsons L, Markou A, Weiss F. Opponent process model and psychostimulant addiction. Pharmacology, Biochemistry \& Behavior 1997;57:513-21.

[17] Le Foll B, Forget B, Aubin H-J, Goldberg SR. Blocking cannabinoid CB1 receptors for the treatment of nicotine dependence: insights from pre-clinical and clinical studies. Addiction Biology 2008;13:239-52.

[18] Gonzalez S, Cascio MG, Fernandez-Ruiz J, Fezza F, Di Marzo V, Ramos JA. Changes in endocannabinoid contents in the brain of rats chronically exposed to nicotine, ethanol or cocaine. Brain Research 2002;954:73-81.

[19] Shoaib M. The cannabinoid antagonist AM251 attenuates nicotine self-administration and nicotine-seeking behaviour in rats. Neuropharmacology 2008;54:438-44. 
[20] Cohen C, Perrault G, Griebel G, Soubrie P. Nicotine-associated cues maintain nicotine-seeking behavior in rats several weeks after nicotine withdrawal: reversal by the cannabinoid (CB1) receptor antagonist, rimonabant (SR141716).

Neuropsychopharmacology 2005;30:145-55.

[21] Cohen C, Perrault G, Voltz C, Steinberg R, Soubrie P. SR141716, a central cannabinoid (CB(1)) receptor antagonist, blocks the motivational and dopaminereleasing effects of nicotine in rats. Behavioural Pharmacology 2002;13:451-63.

[22] Le Foll B, Goldberg SR. Rimonabant, a CB1 antagonist, blocks nicotine-conditioned place preferences. Neuroreport 2004;15:2139-43.

[23] Castane A, Valjent E, Ledent C, Parmentier M, Maldonado R, Valverde O. Lack of CB1 cannabinoid receptors modifies nicotine behavioural responses, but not nicotine abstinence. Neuropharmacology 2002;43:857-67.

[24] Cahill K, Ussher M. Cannabinoid type 1 receptor anatagonists (rimonabant) for smoking cessation. The Cochrane Library 2008.

[25] Witkin JM, Tzavara ET, Nomikos GG. A role for cannabinoid CB1 receptors in mood and anxiety disorders. Behavioural Pharmacology 2005;16:315-31.

[26] Berridge KC. Measuring hedonic impact in animals and infants: microstructure of affective taste reactivity patterns. Neuroscience \& Biobehavioral Reviews 2000;24:173-98.

[27] Rideout HJ, Parker LA. Morphine enhancement of sucrose palatability: analysis by the taste reactivity test. Pharmacology, Biochemistry \& Behavior 1996;53:731-4.

[28] Doyle TG, Berridge KC, Gosnell BA. Morphine enhances hedonic taste palatability in rats. Pharmacology, Biochemistry \& Behavior 1993;46:745-9.

[29] Parker LA, Maier S, Rennie M, Crebolder J. Morphine- and naltrexone-induced modification of palatability: analysis by the taste reactivity test. Behavioral Neuroscience 1992;106:999-1010.

[30] Clarke SN, Parker LA. Morphine-induced modification of quinine palatability: effects of multiple morphine-quinine trials. Pharmacology, Biochemistry \& Behavior 1995;51:505-8.

[31] Parker L, Leeb K. Amphetamine-induced modification of quinine palatability: analysis by the taste reactivity test. Pharmacology, Biochemistry \& Behavior 1994;47:413-20.

[32] Kenny PJ, Markou A. Neurobiology of the nicotine withdrawal syndrome. Pharmacology, Biochemistry \& Behavior 2001;70:531-49.

[33] Gatley SJ, Lan R, Pyatt B, Gifford AN, Volkow ND, Makriyannis A. Binding of the non-classical cannabinoid CP 55,940, and the diarylpyrazole AM251 to rodent brain cannabinoid receptors. Life Sciences 1997;61:PL 191-7.

[34] Wing VC, Shoaib M. A second order schedule of nicotine reinforcement in the rat to examine the role of endocannabinoids. submitted 2009.

[35] Damaj MI, Kao W, Martin BR. Characterization of spontaneous and precipitated nicotine withdrawal in the mouse. Journal of Pharmacology \& Experimental Therapeutics 2003;307:526-34.

[36] Davis JA, Gould TJ. Atomoxetine reverses nicotine withdrawal-associated deficits in contextual fear conditioning. Neuropsychopharmacology 2007;32:2011-9.

[37] Corbille A-G, Valjent E, Marsicano G, Ledent C, Lutz B, Herve D, et al. Role of cannabinoid type 1 receptors in locomotor activity and striatal signaling in response to psychostimulants. Journal of Neuroscience 2007;27:6937-47.

[38] Haller J, Matyas F, Soproni K, Varga B, Barsy B, Nemeth B, et al. Correlated species differences in the effects of cannabinoid ligands on anxiety and on GABAergic and 
glutamatergic synaptic transmission. European Journal of Neuroscience 2007;25:2445-56.

[39] Cagniard B, Murphy N. Taste Reactivity and its modulation by morphine and methamphetamine in C57BL/6 and DBA/2 mice. Physiology \& Behavior 2009;96:412-20.

[40] Kiefer SW, Hill KG, Kaczmarek HJ. Taste reactivity to alcohol and basic tastes in outbred mice. Alcoholism: Clinical \& Experimental Research 1998;22:1146-51.

[41] Pecina S, Berridge KC. Hedonic hot spot in nucleus accumbens shell: where do muopioids cause increased hedonic impact of sweetness? Journal of Neuroscience 2005;25:11777-86.

[42] Mahler SV, Smith KS, Berridge KC. Endocannabinoid hedonic hotspot for sensory pleasure: anandamide in nucleus accumbens shell enhances 'liking' of a sweet reward. Neuropsychopharmacology 2007;32:2267-78.

[43] Pecina S, Cagniard B, Berridge KC, Aldridge JW, Zhuang X. Hyperdopaminergic mutant mice have higher "wanting" but not "liking" for sweet rewards. Journal of Neuroscience 2003;23:9395-402.

[44] Marks MJ, Stitzel JA, Collins AC. Genetic influences on nicotine responses. Pharmacology, Biochemistry \& Behavior 1989;33:667-78.

[45] Damaj MI, Welch SP, Martin BR. Characterization and modulation of acute tolerance to nicotine in mice. Journal of Pharmacology \& Experimental Therapeutics 1996;277:454-61.

[46] Damaj MI, Welch SP, Martin BR. In vivo pharmacological effects of dihydro-betaerythroidine, a nicotinic antagonist, in mice. Psychopharmacology 1995;117:67-73.

[47] Valjent E, Mitchell JM, Besson MJ, Caboche J, Maldonado R. Behavioural and biochemical evidence for interactions between Delta 9-tetrahydrocannabinol and nicotine. British Journal of Pharmacology 2002;135:564-78.

[48] McLaughlin PJ, Winston K, Swezey L, Wisniecki A, Aberman J, Tardif DJ, et al. The cannabinoid CB1 antagonists SR 141716A and AM 251 suppress food intake and food-reinforced behavior in a variety of tasks in rats. Behavioural Pharmacology 2003;14:583-8.

[49] Parker LA, Doucet K. The effects of nicotine and nicotine withdrawal on taste reactivity. Pharmacology, Biochemistry \& Behavior 1995;52:125-9.

[50] Marks MJ, Miner L, Burch JB, Fulker DW, Collins AC. A diallel analysis of nicotineinduced hypothermia. Pharmacology, Biochemistry \& Behavior 1984;21:953-9.

[51] Itzhak Y, Martin JL. Effects of cocaine, nicotine, dizocipline and alcohol on mice locomotor activity: cocaine-alcohol cross-sensitization involves upregulation of striatal dopamine transporter binding sites. Brain Research 1999;818:204-11.

[52] Marks MJ, Burch JB, Collins AC. Genetics of nicotine response in four inbred strains of mice. Journal of Pharmacology \& Experimental Therapeutics 1983;226:291-302.

[53] Marks MJ, Burch JB, Collins AC. Effects of chronic nicotine infusion on tolerance development and nicotinic receptors. Journal of Pharmacology \& Experimental Therapeutics 1983;226:817-25.

[54] Epping-Jordan MP, Watkins SS, Koob GF, Markou A. Dramatic decreases in brain reward function during nicotine withdrawal. Nature 1998;393:76-9.

[55] Davis JA, James JR, Siegel SJ, Gould TJ. Withdrawal from chronic nicotine administration impairs contextual fear conditioning in C57BL/6 mice. Journal of Neuroscience 2005;25:8708-13.

[56] Metzger KL, Maxwell CR, Liang Y, Siegel SJ. Effects of nicotine vary across two auditory evoked potentials in the mouse. Biological Psychiatry 2007;61:23-30. 
[57] Moyer TP, Charlson JR, Enger RJ, Dale LC, Ebbert JO, Schroeder DR, et al. Simultaneous analysis of nicotine, nicotine metabolites, and tobacco alkaloids in serum or urine by tandem mass spectrometry, with clinically relevant metabolic profiles. Clinical Chemistry 2002;48:1460-71.

[58] Shoaib M, Stolerman IP, Kumar RC. Nicotine-induced place preferences following prior nicotine exposure in rats. Psychopharmacology 1994;113:445-52.

[59] Koob GF. Neurobiological substrates for the dark side of compulsivity in addiciton Neuropharmacology 2008;in press.

[60] Malin DH, Lake JR, Carter VA, Cunningham JS, Hebert KM, Conrad DL, et al. The nicotinic antagonist mecamylamine precipitates nicotine abstinence syndrome in the rat. Psychopharmacology 1994;115:180-4.

[61] Hildebrand BE, Nomikos GG, Bondjers C, Nisell M, Svensson TH. Behavioral manifestations of the nicotine abstinence syndrome in the rat: peripheral versus central mechanisms. Psychopharmacology 1997;129:348-56.

[62] Suzuki T, Ise Y, Tsuda M, Maeda J, Misawa M. Mecamylamine-precipitated nicotinewithdrawal aversion in rats. European Journal of Pharmacology 1996;314:281-4.

[63] Helton DR, Modlin DL, Tizzano JP, Rasmussen K. Nicotine withdrawal: a behavioral assessment using schedule controlled responding, locomotor activity, and sensorimotor reactivity. Psychopharmacology 1993;113:205-10.

[64] Costall B, Kelly ME, Naylor RJ, Onaivi ES. The actions of nicotine and cocaine in a mouse model of anxiety. Pharmacology, Biochemistry \& Behavior 1989;33:197-203.

[65] Mannucci C, Tedesco M, Bellomo M, Caputi AP, Calapai G. Long-term effects of nicotine on the forced swimming test in mice: an experimental model for the study of depression caused by smoke. Neurochemistry International 2006;49:481-6.

[66] Hughes JR, Hughes JR. Effects of abstinence from tobacco: valid symptoms and time course.[see comment]. Nicotine \& Tobacco Research 2007;9:315-27.

[67] Isola R, Vogelsberg V, Wemlinger TA, Neff NH, Hadjiconstantinou M. Nicotine abstinence in the mouse. Brain Research 1999;850:189-96.

[68] Jonkman S, Henry B, Semenova S, Markou A. Mild anxiogenic effects of nicotine withdrawal in mice. European Journal of Pharmacology 2005;516:40-5.

[69] Johnson PM, Hollander JA, Kenny PJ. Decreased brain reward function during nicotine withdrawal in C57BL6 mice: Evidence from intracranial self-stimulation (ICSS) studies. Pharmacology, Biochemistry \& Behavior 2008;90:409-15.

[70] Stoker AK, Semenova S, Markou A. Affective and somatic aspects of spontaneous and precipitated nicotine withdrawal in C57BL/6J and BALB/cByJ mice. Neuropharmacology 2008;54:1223-32.

[71] Portugal GS, Gould TJ. Nicotine withdrawal disrupts new contextual learning. Pharmacology, Biochemistry \& Behavior 2009;92:117-23.

[72] Rauhut AS, Hawrylak M, Mardekian SK. Bupropion differentially alters the aversive, locomotor and rewarding properties of nicotine in CD-1 mice. Pharmacology, Biochemistry \& Behavior 2008;90:598-607.

[73] Tammimaki A, Chistyakov V, Patkina N, Skippari J, Ahtee L, Zvartau E, et al. Effect of forced chronic oral nicotine exposure on intravenous self-administration and rewarding properties of acute nicotine. European Journal of Pharmacology 2008;591:164-70.

[74] Caggiula AR, Donny EC, Chaudhri N, Perkins KA, Evans-Martin FF, Sved AF. Importance of nonpharmacological factors in nicotine self-administration. Physiology \& Behavior 2002;77:683-7. 
[75] Caggiula AR, Donny EC, White AR, Chaudhri N, Booth S, Gharib MA, et al. Cue dependency of nicotine self-administration and smoking. Pharmacology, Biochemistry \& Behavior 2001;70:515-30.

[76] Conklin CA. Environments as cues to smoke: implications for human extinctionbased research and treatment. Experimental \& Clinical Psychopharmacology 2006;14:12-9.

[77] Wing VC, Shoaib M. Contextual stimuli modulate the extinction and reinstatement in rodents self-administering intravenous nicotine. Psychopharmacology 2008;200:35765.

[78] Donny EC, Chaudhri N, Caggiula AR, Evans-Martin FF, Booth S, Gharib MA, et al. Operant responding for a visual reinforcer in rats is enhanced by noncontingent nicotine: implications for nicotine self-administration and reinforcement.[see comment]. Psychopharmacology 2003;169:68-76.

[79] Jarrett MM, Scantlebury J, Parker LA. Effect of delta9-tetrahydrocannabinol on quinine palatability and AM251 on sucrose and quinine palatability using the taste reactivity test. Physiology \& Behavior 2007;90:425-30.

[80] Jarrett MM, Limebeer CL, Parker LA. Effect of Delta9-tetrahydrocannabinol on sucrose palatability as measured by the taste reactivity test. Physiology \& Behavior 2005;86:475-9.

[81] Fattore L, Fadda P, Fratta W. Endocannabinoid regulation of relapse mechanisms. Pharmacological Research 2007;56:418-27.

[82] Berridge KC, Grill HJ. Isohedonic tastes support a two-dimensional hypothesis of palatability. Appetite 1984;5:221-31. 
Table and Figure Legends

Table 1. Affective taste reactivity results of Experiment 1. Mean score $( \pm S E M)$ for each taste reactivity measure (positive, negative, neutral and behavioural activity) produced by vehicleand nicotine-treated animals during sucrose or quinine infusion in the four affective taste reactivity tests.

Table 2. Affective taste reactivity results of Experiment 2. Mean score $( \pm S E M)$ for each taste reactivity measure (positive, negative, neutral and behavioural activity) produced by vehicleand nicotine-treated animals during sucrose or quinine infusion in the four affective taste reactivity tests [vehicle; AM251 (1mg/kg); AM251 (3mg/kg); AM251 (10mg/kg)].

Figure 1. Graphs showing affective taste reactivity results for selected measures during sucrose infusion in experiment 1. Mean scores ( \pm SEM) for vehicle- and nicotine-treated groups are shown across the four affective taste reactivity tests. Panel f provides a graphical representation of the experimental protocol. * $-p<0.05$ ** $-p<0.01$, Bonferroni pairwise comparisons following one-way ANOVAs within vehicle- or nicotine-treated groups across the four affective taste reactivity tests.

Figure 2. Graphs showing affective taste reactivity results for selected measures during quinine infusion in experiment 1 . Mean scores ( \pm SEM) for vehicle- and nicotine-treated groups are shown across the four affective taste reactivity tests.. * $-p<0.05{ }^{* *}-p<0.01$, Bonferroni pairwise comparisons following one-way ANOVAs within vehicle- or nicotinetreated groups across the four affective taste reactivity tests.

Figure 3. Graphs showing affective taste reactivity results for selected measures during sucrose infusion in experiment 2. Mean scores ( $($ SEM) for vehicle- and nicotine-treated groups are shown across the four affective taste reactivity tests [vehicle; AM251 (1mg/kg); 
AM251 (3mg/kg); AM251 (10mg/kg)]. Panel f provides a graphical representation of the experimental protocol. * $-p<0.05$ and ${ }^{*}$ - $p<0.01$ : Bonferroni pairwise comparisons following one-way ANOVAs within vehicle- or nicotine-treated groups across the four affective taste reactivity tests. $\#$ - $p$ <0.05: Independent t-tests between vehicle- and nicotine-treated groups at specific affective taste reactivity tests.

Figure 4. Graphs showing affective taste reactivity results for selected measures during quinine infusion in experiment 2. Mean scores $( \pm$ SEM) for vehicle- and nicotine-treated groups are shown across the four affective taste reactivity tests [vehicle; AM251 (1mg/kg); AM251 (3mg/kg); AM251 (10mg/kg)]. * $-p<0.05$ and ** $-p<0.01$ : Bonferroni pairwise comparisons following one-way ANOVAs within vehicle- or nicotine-treated groups across the four affective taste reactivity tests. \# - $p<0.05$ : Independent t-tests between vehicle- and nicotine-treated groups at specific affective taste reactivity tests. 


\begin{tabular}{|c|c|c|c|c|c|c|c|c|c|}
\hline \multirow[b]{2}{*}{ Response } & \multirow[b]{2}{*}{ Treatment } & \multicolumn{4}{|c|}{$\begin{array}{c}\text { Sucrose } \\
\text { DAY }\end{array}$} & \multicolumn{4}{|c|}{$\begin{array}{l}\text { Quinine } \\
\text { DAY }\end{array}$} \\
\hline & & $\begin{array}{c}1 \\
\text { Chronic } \\
\text { treatment } \\
\text { day1 } \\
\end{array}$ & $\begin{array}{c}11 \\
\text { Chronic } \\
\text { treatment } \\
\text { day11 } \\
\end{array}$ & $\begin{array}{c}13 \\
\text { Day } 1 \text { after } \\
\text { removal of } \\
\text { minipump }\end{array}$ & $\begin{array}{l}20 \\
\text { Day } 7 \text { after } \\
\text { removal of } \\
\text { minipump }\end{array}$ & $\begin{array}{c}1 \\
\text { Chronic } \\
\text { treatment } \\
\text { day1 } \\
\end{array}$ & $\begin{array}{c}11 \\
\text { Chronic } \\
\text { treatment } \\
\text { day11 } \\
\end{array}$ & $\begin{array}{c}13 \\
\text { Day } 1 \text { after } \\
\text { removal of } \\
\text { minipump }\end{array}$ & $\begin{array}{c}20 \\
\text { Day } 7 \text { after } \\
\text { removal of } \\
\text { minipump }\end{array}$ \\
\hline \multicolumn{10}{|l|}{ Positive } \\
\hline \multirow[t]{2}{*}{ Rhythmic tongue } & Vehicle & $1.4(0.7)$ & $2.0(1.1)$ & $1.9(1.1)$ & $3.1(3.1)$ & $0.1(0.1)$ & 0 & 0 & 0 \\
\hline & Nicotine & $4.0(2.0)$ & $2.8(2.1)$ & $2.8(1.9)$ & $3.4(1.7)$ & 0 & 0 & 0 & 0 \\
\hline \multirow[t]{2}{*}{ Single tongue } & Vehicle & $3.0(1.2)$ & $1.9(0.6)$ & $2.4(1.5)$ & $1.4(0.6)$ & $4.3(2.7)$ & $0.3(0.2)$ & $0.8(0.6)$ & 0 \\
\hline & Nicotine & $1.0(0.5)$ & $1.5(1.2)$ & $1.5(0.7)$ & $0.7(0.4)$ & $0.3(0.3)$ & $0.5(0.4)$ & $0.5(0.2)$ & $0.5(0.3)$ \\
\hline \multirow[t]{2}{*}{ Paw licking } & Vehicle & $8.1(1.6)$ & 6.9 (1.9) & $6.75(1.5)$ & $6.0(1.6)$ & $0.9(0.4)$ & 0 & $0.4(0.3)$ & 0 \\
\hline & Nicotine & $6.6(2.0)$ & $6.6(2.0)$ & $6.2(1.5)$ & $5.2(1.0)$ & $0.4(0.2)$ & $0.1(0.1)$ & $0.5(0.2)$ & 0 \\
\hline \multicolumn{10}{|l|}{ Aversive } \\
\hline \multirow[t]{2}{*}{ Flails } & Vehicle & $4.1(1.2)$ & $5.1(1.6)$ & $2.6(1.5)$ & $2.0(1.3)$ & $5.8(1.1)$ & $9.8(4.2)$ & $10.8(2.8)$ & $15.9(5.4)$ \\
\hline & Nicotine & $3.9(1.9)$ & 3.7 (1.9) & $2.6(0.7)$ & $2.5(0.9)$ & $5.4(1.7)$ & $7.8(2.6)$ & $10.4(2.4)$ & $12.6(3.3)$ \\
\hline \multirow[t]{2}{*}{ Headshakes } & Vehicle & $0.5(0.3)$ & $0.5(0.2)$ & $0.4(0.3)$ & 0 & $1.0(0.5)$ & $1.3(0.4)$ & $1.0(0.3)$ & $1.3(0.4)$ \\
\hline & Nicotine & $0.5(0.3)$ & $0.3(0.3)$ & $0.7(0.3)$ & $0.6(0.5)$ & $0.8(0.2)$ & $1.7(0.6)$ & $1.2(0.3)$ & $0.9(0.4)$ \\
\hline \multicolumn{10}{|l|}{ Neutral } \\
\hline \multirow[t]{2}{*}{ Mouth movement } & Vehicle & $7.5(1.6)$ & $6.5(2.2)$ & $6.8(1.0)$ & $3.0(0.6)$ & $9.5(2.5)$ & $6.1(1.5)$ & $7.5(1.3)$ & $8.3(1.4)$ \\
\hline & Nicotine & $8.5(2.3)$ & $6.1(1.3)$ & $5.9(1.5)$ & $4.2(1.3)$ & $8.2(1.3)$ & $6.8(1.5)$ & $9.0(1.6)$ & $7.4(1.6)$ \\
\hline \multirow[t]{2}{*}{ Grooming } & Vehicle & $5.8(1.4)$ & 4.88 (1.37) & 7.13 (2.23) & $8.63(1.55)$ & $2.3(1.1)$ & $2.5(0.8)$ & $2.5(0.8)$ & $3.1(0.7)$ \\
\hline & Nicotine & $3.6(1.3)$ & $7.1(1.8)$ & $6.7(1.0)$ & $6.1(1.0)$ & $2.9(1.0)$ & $2.7(1.4)$ & $1.6(0.7)$ & $1.7(0.7)$ \\
\hline \multicolumn{10}{|l|}{$\begin{array}{l}\text { Behavioural } \\
\text { Activity }\end{array}$} \\
\hline \multirow[t]{2}{*}{ Rearing } & Vehicle & $5.1(0.8)$ & $4.1(1.0)$ & $4.6(0.8)$ & $4.3(1.0)$ & $8.0(1.3)$ & $8.4(1.4)$ & $7.1(1.5)$ & $9.5(2.7)$ \\
\hline & Nicotine & $3.7(0.9)$ & $5.5(1.6)$ & $4.5(1.4)$ & $5.8(1.4)$ & $5.4(1.6)$ & $8.4(1.6)$ & $7.2(1.2)$ & $9.7(1.8)$ \\
\hline \multirow[t]{2}{*}{ Horizontal activity } & Vehicle & $0.4(0.4)$ & $2.8(1.3)$ & $0.4(0.2)$ & $0.4(0.2)$ & $4.1(1.4)$ & $8.4(1.9)$ & 4.9 (1.3) & $9.4(2.8)$ \\
\hline & Nicotine & $0.3(0.2)$ & $0.4(0.3)$ & $0.9(0.5)$ & $2.3(1.1)$ & $5.8(1.6)$ & $6.5(1.9)$ & $4.7(0.9)$ & $10.1(3.0)$ \\
\hline
\end{tabular}




\begin{tabular}{|c|c|c|c|c|c|c|c|c|c|}
\hline \multirow[b]{2}{*}{ Response } & \multirow[b]{2}{*}{ Treatment } & \multicolumn{4}{|c|}{$\begin{array}{c}\text { Sucrose } \\
\text { AM251 (mg/kg) }\end{array}$} & \multicolumn{4}{|c|}{$\begin{array}{c}\text { Quinine } \\
\text { AM251 (mg/kg) }\end{array}$} \\
\hline & & 0 & 1 & 3 & 10 & 0 & 1 & 3 & 10 \\
\hline \multirow{3}{*}{$\begin{array}{l}\text { Positive } \\
\text { Rhythmic tongue }\end{array}$} & & & & & & & & & \\
\hline & Vehicle & $1.3(0.6)$ & $2.2(1.1)$ & $1.8(1.2)$ & $1.2(0.5)$ & $0.2(0.2)$ & 0 & 0 & 0 \\
\hline & Nicotine & $0.5(0.3)$ & $1.2(0.7)$ & $1.2(1.0)$ & $1.4(0.6)$ & 0 & 0 & 0 & 0 \\
\hline \multirow[t]{2}{*}{ Single tongue } & Vehicle & $1.3(0.7)$ & $1.8(1.0)$ & $1.2(0.8)$ & $1.3(0.4)$ & $0.8(0.7)$ & $0.7(0.7)$ & 0 & $0.5(0.3)$ \\
\hline & Nicotine & $1.3(0.8)$ & $1.7(0.7)$ & $0.8(0.8)$ & $0.2(0.2)$ & $0.5(0.2)$ & $0.5(0.5)$ & $0.2(0.2)$ & $0.2(0.2)$ \\
\hline \multirow[t]{2}{*}{ Paw licking } & Vehicle & $6.2(2.0)$ & $4.0(1.8)$ & $1.5(1.5)$ & $1.8(1.8)$ & $0.5(0.3)$ & 0 & $0.3(0.2)$ & 0 \\
\hline & Nicotine & $5.3(2.0)$ & $5.0(1.7)$ & $5.0(1.9)$ & $4.0(1.8)$ & $0.8(0.5)$ & $0.3(0.3)$ & $0.3(0.3)$ & 0 \\
\hline \multicolumn{10}{|l|}{ Aversive } \\
\hline \multicolumn{10}{|l|}{ Gapes } \\
\hline \multirow[t]{2}{*}{ Flails } & Vehicle & $3.0(0.7)$ & $2.0(0.8)$ & $3.2(1.2)$ & $6.2(5.4)$ & $12.0(3.7)$ & $22.5(5.3)$ & $25.5(5.3)$ & $31.3(9.3)$ \\
\hline & Nicotine & $4.5(2.1)$ & $2.3(1.1)$ & $2.7(0.7)$ & $2.0(1.1)$ & $13.2(1.7)$ & $19.0(5.5)$ & $27.3(5.7)$ & $42.8(9.1)$ \\
\hline \multirow[t]{2}{*}{ Headshakes } & Vehicle & $0.5(0.3)$ & 0 & $1.0(0.5)$ & $0.8(0.8)$ & $1.5(0.43)$ & $1.7(0.6)$ & $1.3(0.5)$ & $3.8(1.0)$ \\
\hline & Nicotine & $1.0(0.4)$ & $0.8(0.4)$ & $1.2(0.5)$ & $1.2(0.8)$ & $2.0(0.7)$ & $4.0(0.8)$ & $4.5(1.4)$ & $5.5(1.5)$ \\
\hline \multicolumn{10}{|l|}{ Neutral } \\
\hline \multirow[t]{2}{*}{ Mouth movement } & Vehicle & $6.5(1.8)$ & $7.2(1.9)$ & $8.5(2.3)$ & $10.0(3.8)$ & $9.7(1.6)$ & $11.0(1.3)$ & $8.2(1.1)$ & $6.0(1.9)$ \\
\hline & Nicotine & $6.2(2.0)$ & $4.2(1.2)$ & $3.7(1.7)$ & $4.8(1.7)$ & $8.5(1.2)$ & $7.3(1.9)$ & $7.7(1.7)$ & $4.8(0.6)$ \\
\hline \multirow[t]{2}{*}{ Grooming } & Vehicle & $6.0(1.5)$ & $4.7(1.1)$ & $5.5(1.9)$ & $6.7(2.1)$ & $5.7(1.4)$ & $3.7(1.1)$ & $2.7(1.1)$ & $5.5(1.8)$ \\
\hline & Nicotine & $6.8(1.0)$ & $7.7(1.3)$ & $8.5(2.1)$ & $7.6(3.0)$ & $3.2(0.9)$ & $4.5(1.2)$ & $3.0(1.2)$ & $3.3(1.0)$ \\
\hline \multicolumn{10}{|l|}{$\begin{array}{l}\text { Behavioural } \\
\text { Activity }\end{array}$} \\
\hline \multirow[t]{2}{*}{ Rearing } & Vehicle & $3.5(1.3)$ & $3.2(1.1)$ & $2.8(1.1)$ & $2.7(1.5)$ & $7.8(2.3)$ & $5.7(1.4)$ & $4.8(2.0)$ & $4.3(1.7)$ \\
\hline & Nicotine & $2.8(0.8)$ & $2.2(0.9)$ & $1.8(0.7)$ & $1.0(0.6)$ & $4.7(1.2)$ & $7.8(2.0)$ & $6.0(1.9)$ & 8.7 (1.9) \\
\hline \multirow[t]{2}{*}{ Horizontal activity } & Vehicle & $3.3(2.4)$ & $1.7(1.3)$ & $2.0(1.2)$ & $0.8(0.4)$ & $9.3(3.6)$ & $5.3(1.6)$ & $3.5(1.1)$ & $11.2(3.0)$ \\
\hline & Nicotine & $3.3(1.6)$ & $0.2(0.2)$ & $0.2(0.2)$ & $0.2(0.2)$ & $10.8(4.4)$ & $8.8(2.7)$ & $9.0(3.0)$ & $8.0(1.2)$ \\
\hline
\end{tabular}




\section{FIGURES}

1.

\section{Chronic nicotine and withdrawal - responses to sucrose}
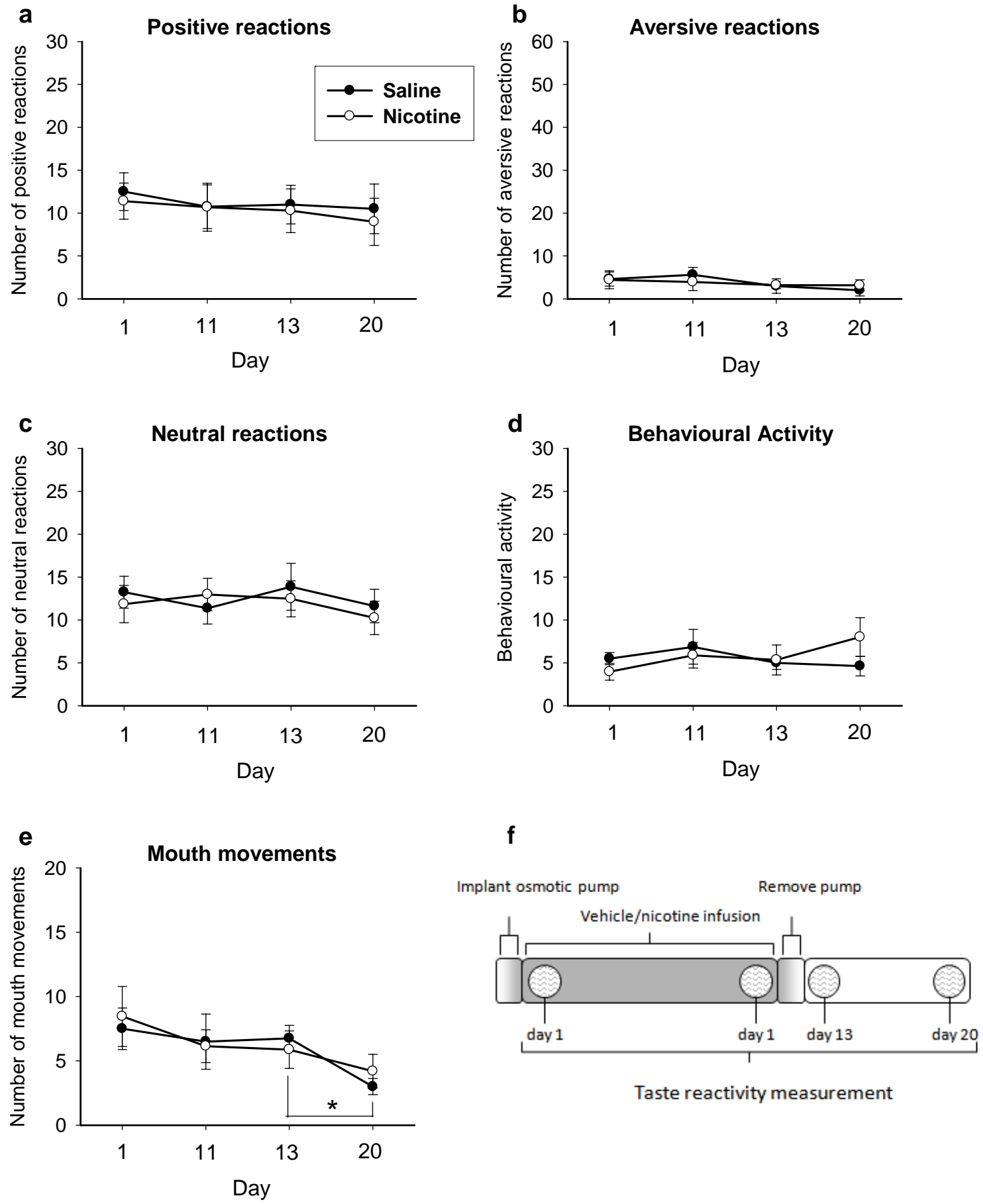
2.

Chronic nicotine and withdrawal - responses to quinine

a
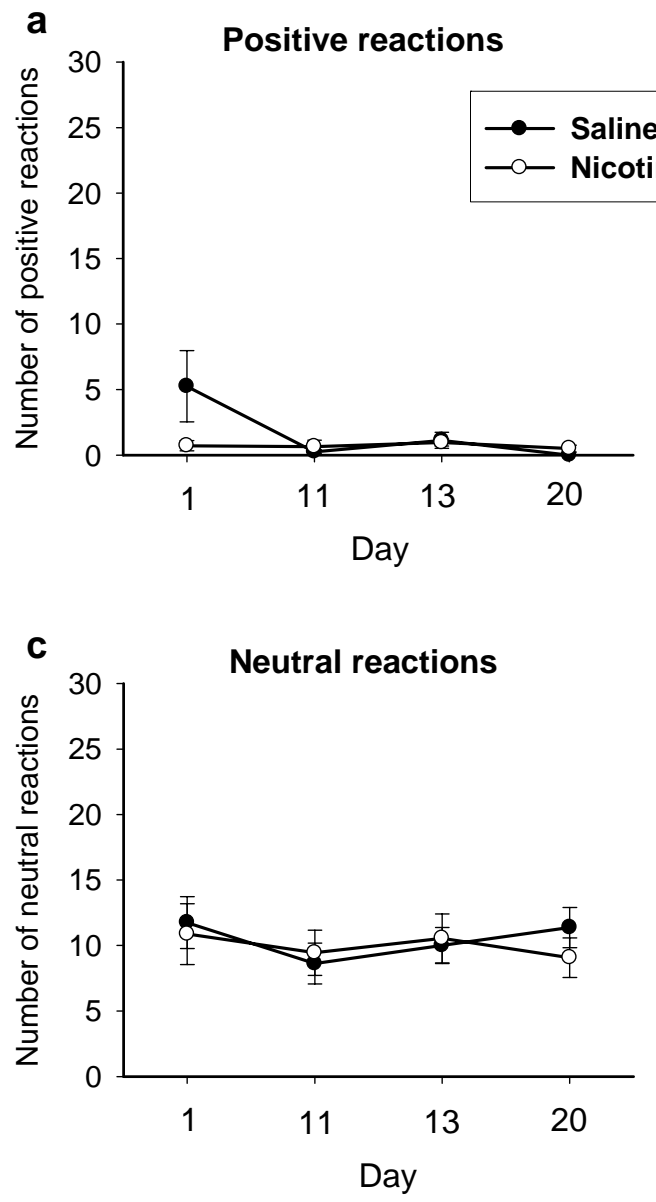

e

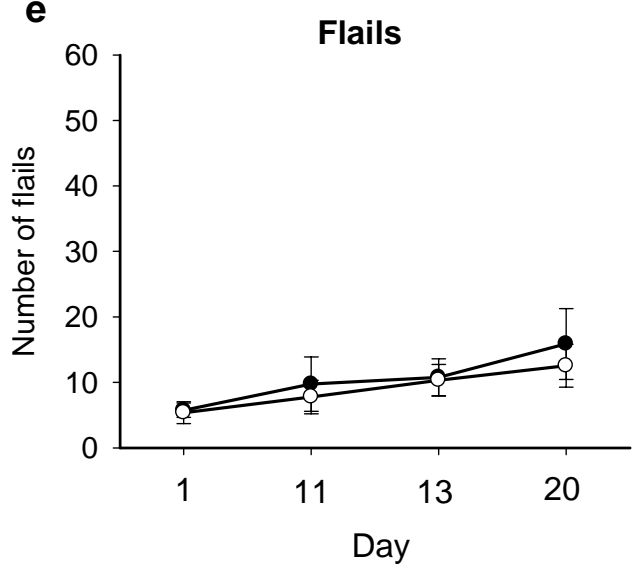

b
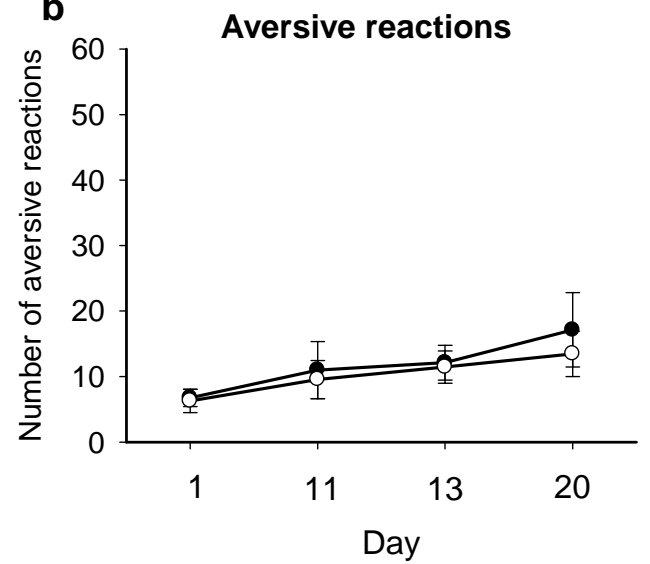

d Behavioural Activity
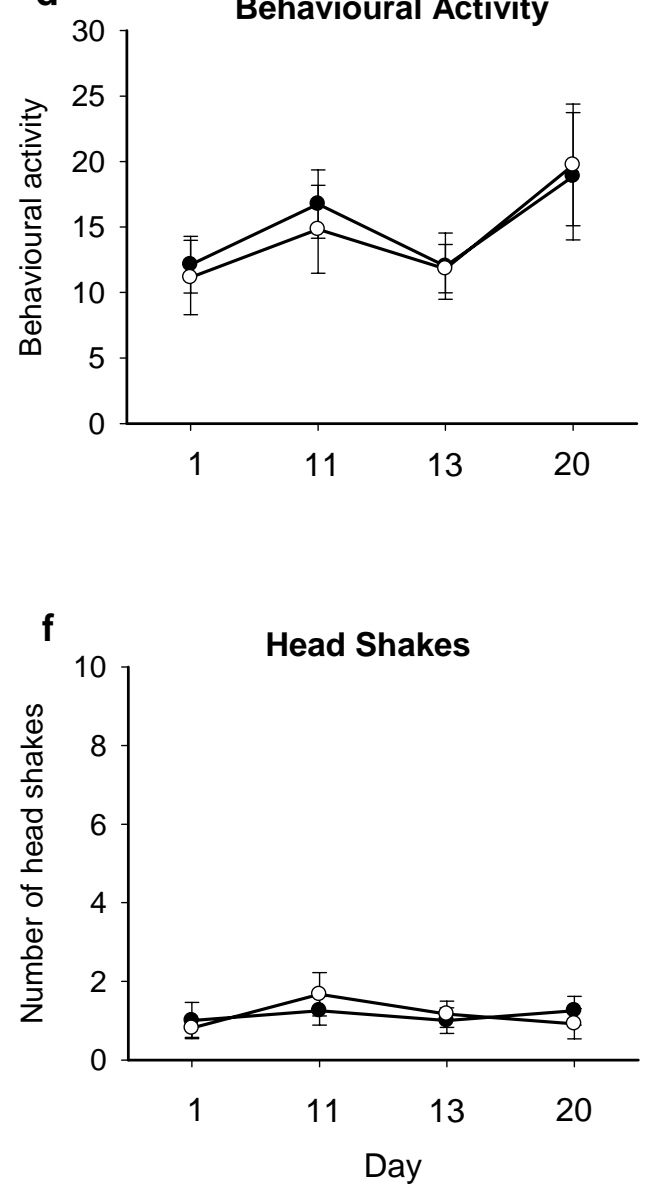
3. Effect of AM251 on chronic nicotine exposure - responses to sucrose

a
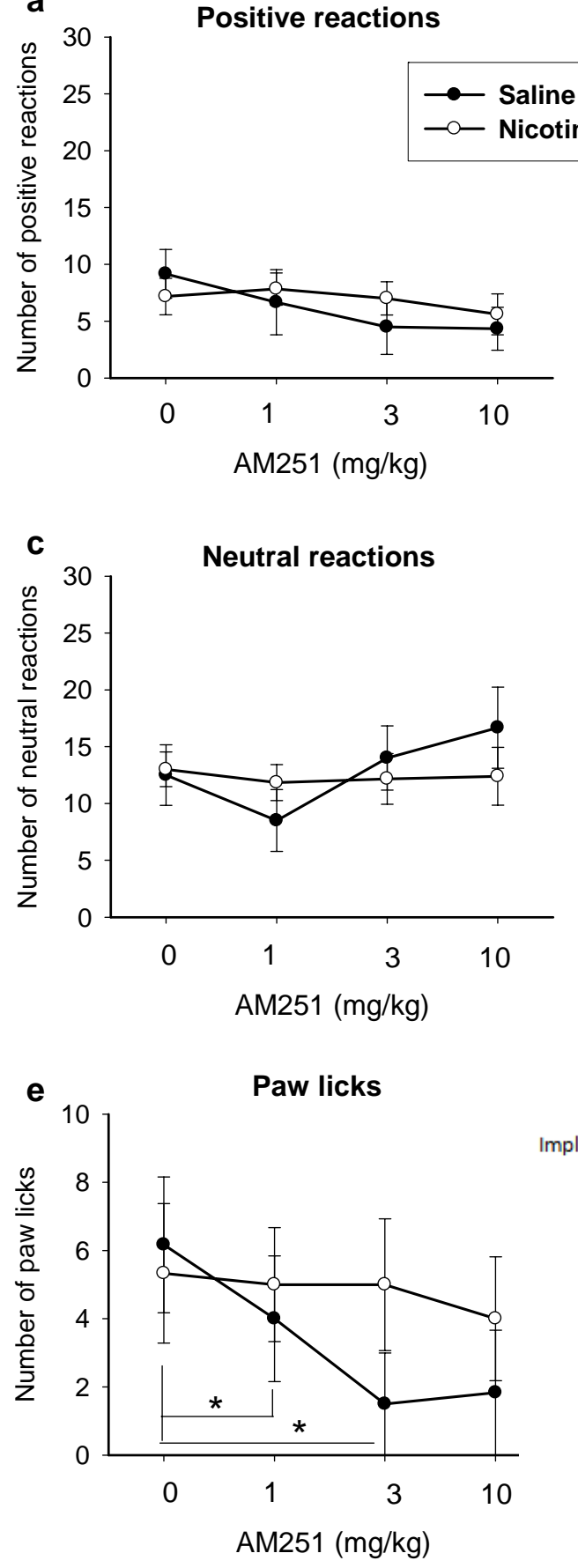

b
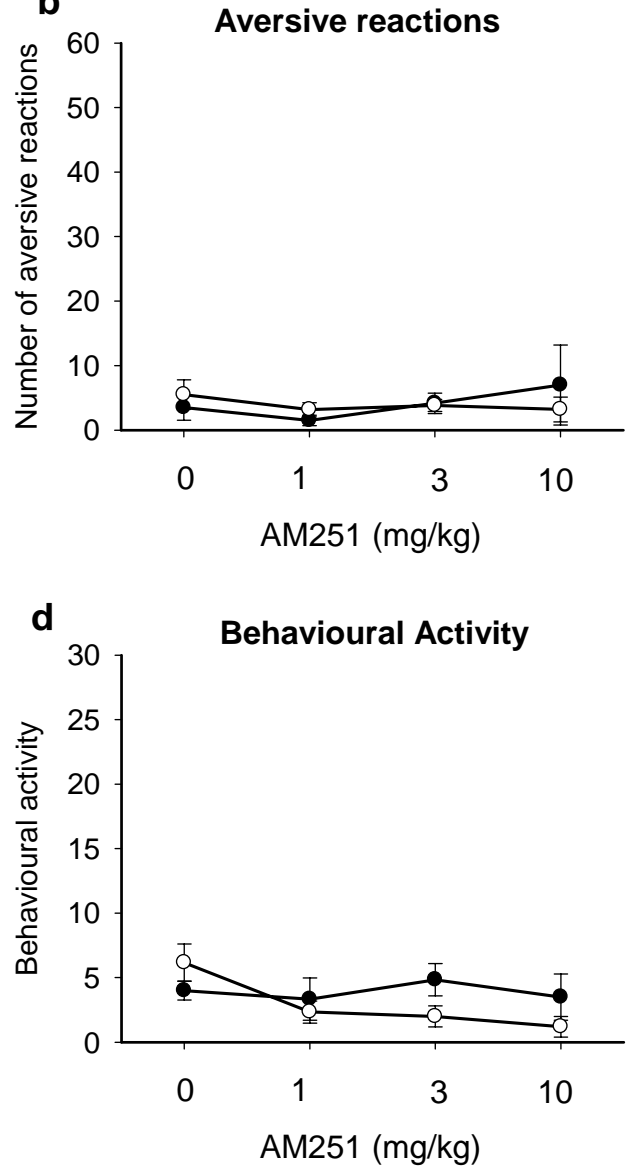

f

Implant osmotic pump

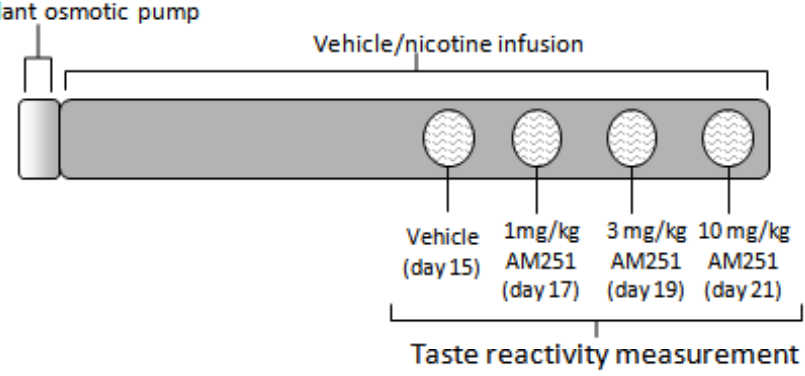


4.

\section{Effect of AM251 on chronic nicotine exposure - responses to quinine}
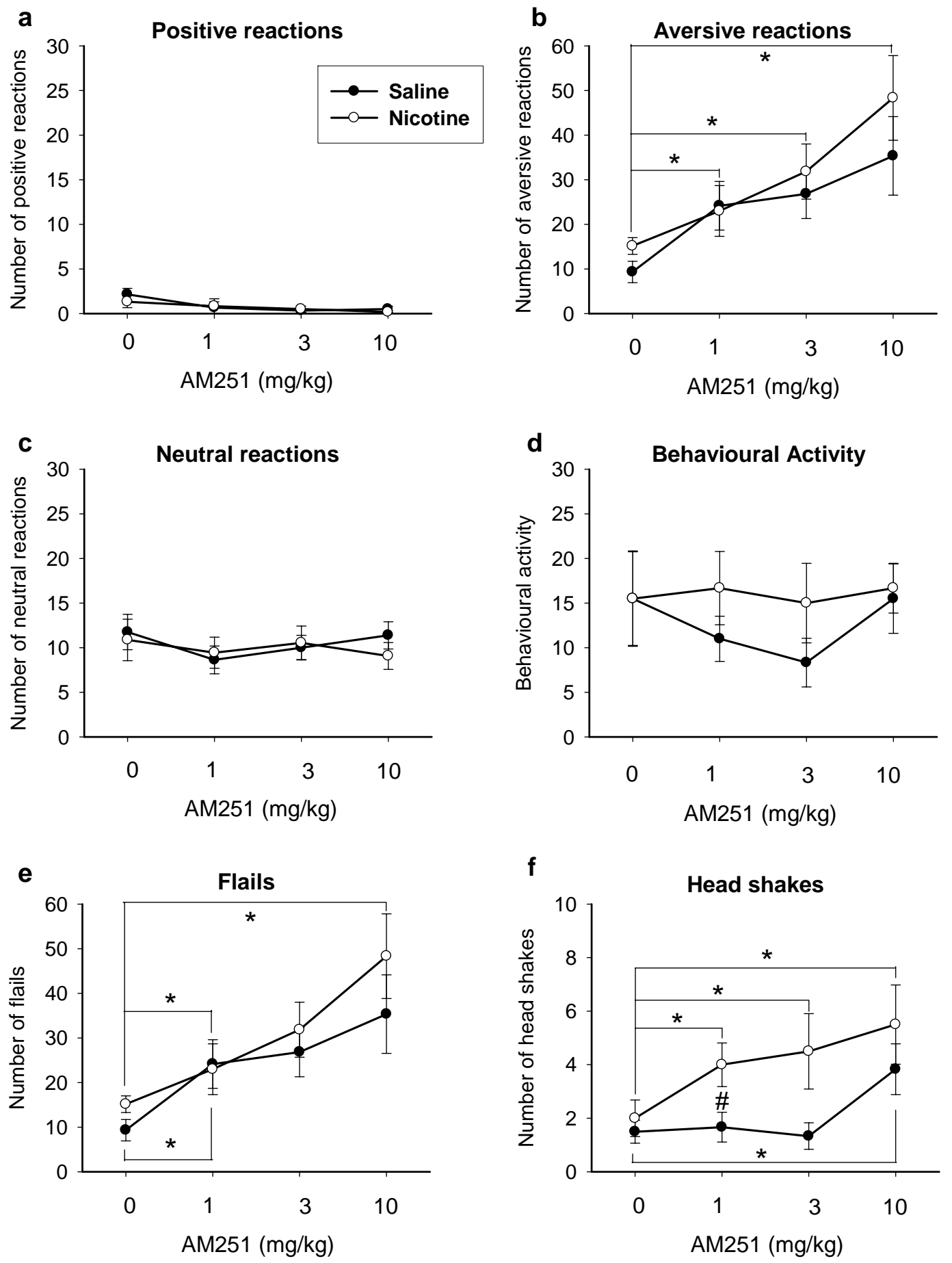
Measurement of affective state during chronic nicotine treatment and withdrawal by affective taste reactivity in mice: the role of endocannabinoids

Victoria C. Wing ${ }^{1}$, Barbara Cagniard ${ }^{2}$, Niall P. Murphy ${ }^{2}$ and Mohammed Shoaib ${ }^{1}$

1. Psychobiology Research Laboratories, Institute of Neuroscience, Newcastle University, Newcastle Upon Tyne, NE2 4HH, UK 2. Molecular Neuropathology Group, RIKEN Brain Science Institute, Wakoshi, Saitama, 351-0198, Japan

\section{Graphical Abstract}
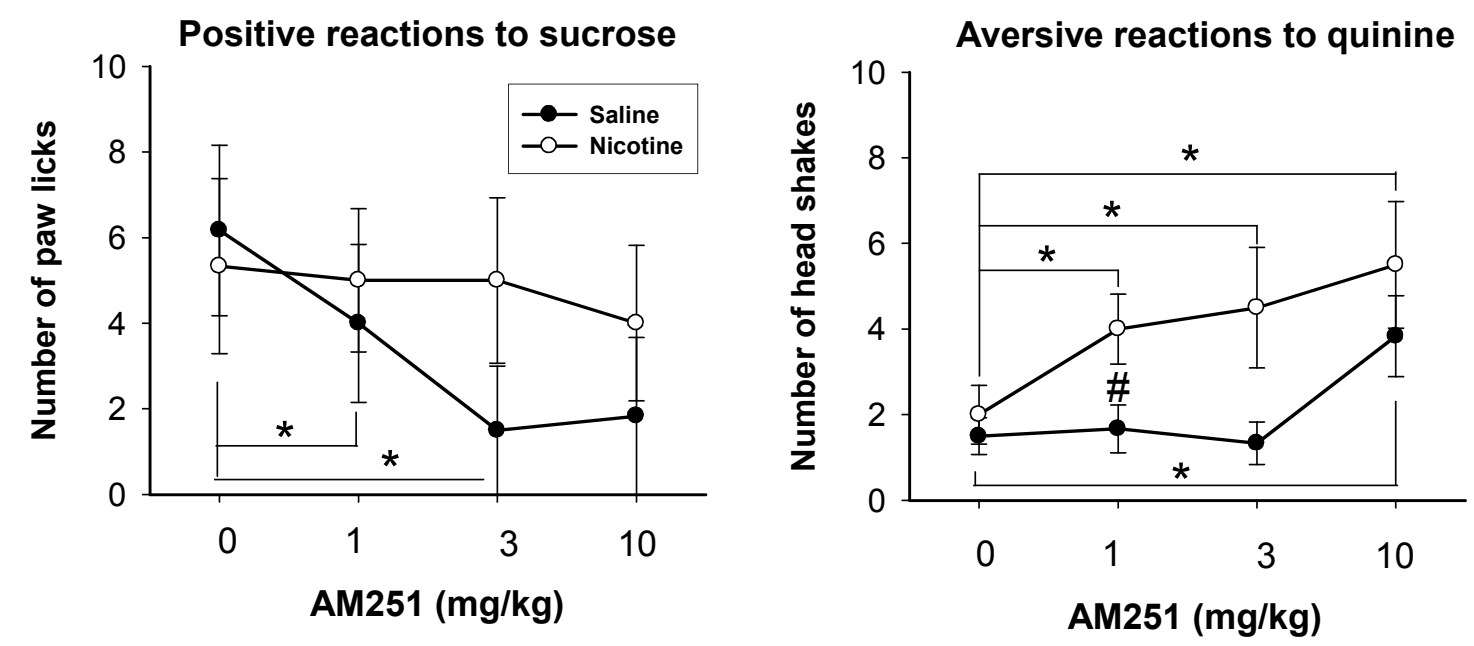

Chronic nicotine treatment and spontaneous withdrawal did not influence taste reactions in mice, whereas AM251 differentially modulated taste reactions in saline and nicotine treated mice. 